\title{
IMPORTANT PLANT AREAS IN THE ARABIAN PENINSULA: 1. JABAL QARAQIR
}

\author{
O.A. Llenellyn ${ }^{1}, M \cdot \mathrm{Hall}^{2,3}, \mathrm{~A} \cdot \mathrm{G} \cdot \mathrm{Miller}^{2}, \mathrm{~T} \cdot \mathrm{M} \cdot \mathrm{Al}_{\mathrm{l}}-\mathrm{Abbasi}{ }^{1}$, \\ A. H. Al $-W_{e t a i d}{ }^{1}, R \cdot J \cdot A l-H a r b i{ }^{1}, K \cdot F \cdot A l-S h a m m a r i{ }^{1} \&$ \\ A. AL-FARHAN ${ }^{4}$
}

Jabal Qaraqir in Saudi Arabia is the first site to be assessed for the Important Plant Area (IPA) programme in the Arabian Peninsula. This paper describes the geology, fauna and flora of the Qaraqir site and provides the first botanical checklist of the area. It designates the locality as an IPA due to the quality of the wadi vegetation and the presence of endemic and biogeographically relictual species. As well as assessments, this study also touches on the planning stage of conservation activity. Socio-economic issues and threats to the conservation of Qaraqir are discussed and suggestions for conservation action are provided.

Keywords. Conservation, Important Plant Area, Qaraqir, refuge, relict species, Saudi Arabia.

\section{IMPORTANT Plant Areas - Introduction}

An Important Plant Area (IPA) programme has recently been adopted for the Arabian Peninsula (Al-Abbasi et al., 2010). This IPA approach to plant conservation has been developed by Plantlife International in response to the successes of Birdlife International's Important Bird Areas programme. These Important Plant Areas are conceived as the most important places in the world for wild plant diversity, and their protection is critical for countering the loss of wild plant species and habitats (Anderson, 2002; Plantlife International, 2004; Al-Abbasi et al., 2010). Important Plant Areas are recognised as a subset of the Key Biodiversity Areas (IUCN, 2007), but the criteria for their selection are more flexible and more suitable for plant conservation. Three broad criteria exist for IPA selection. These concern A threatened species, B - exceptional species richness, and C - threatened habitats. In order for a site to qualify as an IPA, at least one of these criteria must be applicable.

\footnotetext{
${ }^{1}$ National Commission for Wildlife Conservation and Development (NCWCD), PO Box 61681, Riyadh 11575, Kingdom of Saudi Arabia.

2 Centre for Middle Eastern Plants, Royal Botanic Garden Edinburgh, 20A Inverleith Row, Edinburgh EH3 5LR, Scotland, UK.

3 Author for correspondence. E-mail: m.hall@rbge.org.uk

${ }^{4}$ Botany and Microbiology Department, King Saud University, PO Box 2455, Riyadh 11451, Kingdom of Saudi Arabia.
} 
Whilst originally developed for a European context, the IPA criteria have been adapted by the Arabian Plant Specialist Group (APSG) for the Arabian region (AlAbbasi et al., 2010) in order to achieve the targets set down by the Global Strategy for Plant Conservation (Secretariat of the Convention on Biodiversity, 2002). As part of the APSG IPA programme, these revised criteria will be used to assess potential IPA sites across 12 countries. This conservation assessment process will provide both a framework and rationale for the implementation of conservation action in the region (Margules \& Pressey, 2000; Knight et al., 2007). The first of many sites to be assessed for the IPA programme in the Arabian Peninsula is the mountainous area of Jabal Qaraqir in NW Saudi Arabia.

\section{JABAL QARAQIR - INTRODUCTION}

Jabal Qaraqir is one of the most spectacularly beautiful areas in Saudi Arabia. Situated approximately $80 \mathrm{~km}$ south of Tabuk $\left(27^{\circ} 27^{\prime} \mathrm{N}, 36^{\circ} 36^{\prime} \mathrm{E}\right)$, the area is a labyrinth of deep narrow canyons of red and yellow sandstone, that greatly resemble the famous canyon lands of the SW United States (see Figs 1, 2). The site covers a very large area (approximately 160,000 ha) and the altitude ranges from 450 to $1950 \mathrm{~m}$.

The intensively dissected sandstone canyon lands are part of the Hisma plateau and overlie the igneous and metamorphic coastal hills of Madyan. The plateau rises abruptly from low hills of shield rocks, sandy plains and alluvium-floored wadis, and is approximately $45 \times 15 \mathrm{~km}$ in area. Where eroded by backward-cutting wadis from 750 to $1250 \mathrm{~m}$, it is deeply incised into a maze of rock pillars, buttes and pinnacles, with narrow cliff-sided canyons between 300 and $500 \mathrm{~m}$ deep. To the north and east a lava-capped sandstone escarpment looms $500-800 \mathrm{~m}$ above the plateau and extends to the lava flows of the Harrat ar-Raha. The Harrat ar-Raha is punctuated by volcanic cones, plugs and ring dikes and has a summit elevation of approximately $1750 \mathrm{~m}$. For the purposes of conservation planning, this patchwork of different ecological sites is conceived as a single IPA. The high plateau and lower wadi systems are ecologically linked (particularly in terms of water availability), and effective management of these sites cannot be implemented in isolation (Margules \& Pressey, 2000).

There are no precise climatic data for the Jabal Qaraqir site. Measurements from the nearest weather station at Tabuk $(770 \mathrm{~m})$ are shown in Table 1. The Ministry of Agriculture rain gauge at Shuwaq, $25 \mathrm{~km}$ south of Ad-Disah, has recorded an average of $40 \mathrm{~mm}$ per year. At higher altitudes, Jabal Qaraqir receives mainly winter rainfall from the Mediterranean as well as orographic rainfall, frosts and snow. The low wadi channels are hyper-arid.

Jabal Qaraqir is an important site for both plant and animal biodiversity. The area is home to a large population of Nubian ibex Capra ibex nubiana F.Cuvier, estimated in the 1990s to be comprised of 300-550 individuals, the largest ibex population 


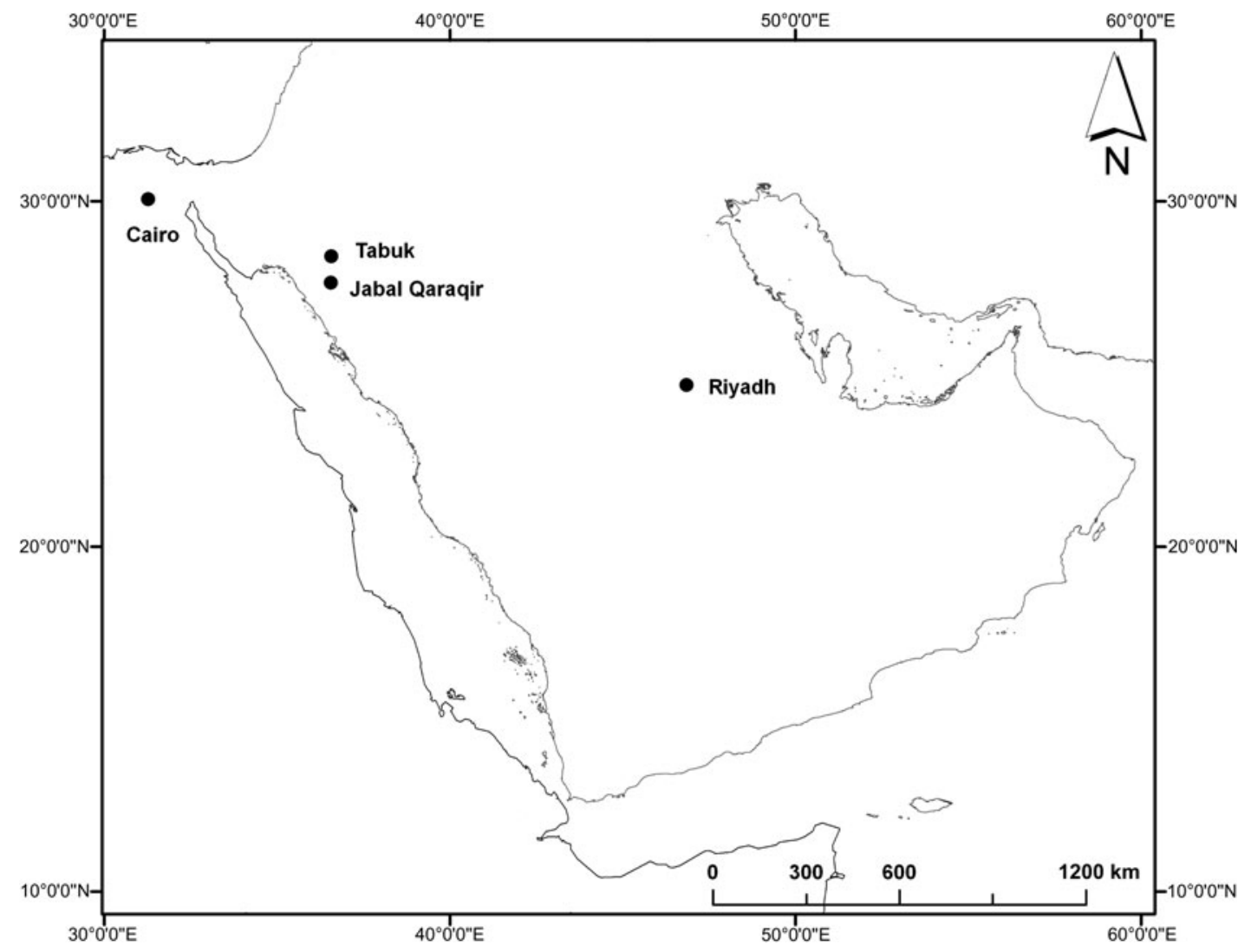

FIg. 1. Jabal Qaraqir is situated $80 \mathrm{~km}$ south of Tabuk, in the far northwest of Saudi Arabia. 


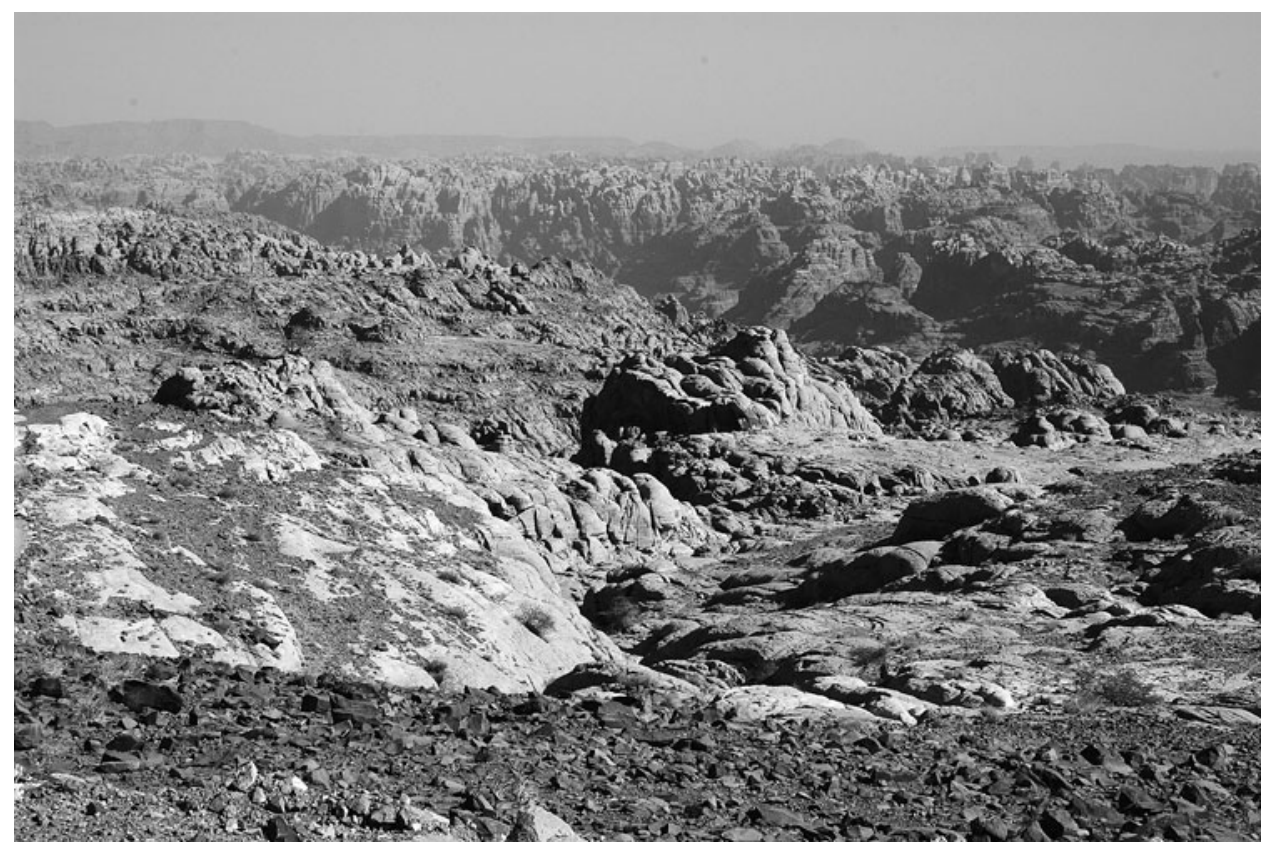

FIG. 2. Jabal Qaraqir is a labyrinth of deep sandstone canyons which greatly resemble the famous canyon lands of the SW United States.

in the Arabian Peninsula. Carnivores include the Arabian wolf Canis lupus arabs Pocock, red fox Vulpes vulpes L., wild cat Felis sylvestris tristrami Pocock, striped hyaena Hyaena hyaena sultana Pocock, caracal Caracal caracal schmitzi Matschie, and honey badger Mellivora capensis Schreber. Mountain gazelle Gazella gazelle

TABLE 1. Comparative measurements from seven major meteorological stations in Saudi Arabia. The station nearest to Jabal Qaraqir is Tabuk. Data adapted from Ghazanfar \& Fisher (1998)

\begin{tabular}{|c|c|c|c|c|c|c|c|}
\hline $\begin{array}{l}\text { Meteorological } \\
\text { station }\end{array}$ & Location & $\begin{array}{l}\text { Altitude } \\
(\mathrm{m})\end{array}$ & $\begin{array}{l}\text { Annual } \\
\text { rainfall } \\
(\mathrm{mm})\end{array}$ & $\begin{array}{l}\text { Maximum } \\
\text { temperature } \\
\left({ }^{\circ} \mathrm{C}\right)\end{array}$ & $\begin{array}{l}\text { Minimum } \\
\text { temperature } \\
\left({ }^{\circ} \mathrm{C}\right)\end{array}$ & $\begin{array}{l}\text { Mean } \\
\text { temperature } \\
\left({ }^{\circ} \mathrm{C}\right)\end{array}$ & $\begin{array}{l}\text { Mean } \\
\text { fog } \\
\text { days }\end{array}$ \\
\hline Tabuk & $28^{\circ} 23^{\prime} \mathrm{N}, 36^{\circ} 34^{\prime} \mathrm{E}$ & 768 & 46 & 44.4 & -3.7 & 22.0 & 0.5 \\
\hline Riyadh & $24^{\circ} 42^{\prime} \mathrm{N}, 46^{\circ} 43^{\prime} \mathrm{E}$ & 614 & 126 & 47.4 & -4.4 & 24.8 & 5.1 \\
\hline Jeddah & $21^{\circ} 33^{\prime} \mathrm{N}, 39^{\circ} 10^{\prime} \mathrm{E}$ & 4 & 47 & 49.0 & 9.8 & 28.4 & 4.8 \\
\hline Jizan & $16^{\circ} 52^{\prime} \mathrm{N}, 42^{\circ} 34^{\prime} \mathrm{E}$ & 7 & 129 & 45.3 & 11.8 & 30.6 & 1.4 \\
\hline Najran & $17^{\circ} 30^{\prime} \mathrm{N}, 44^{\circ} 12^{\prime} \mathrm{E}$ & 1212 & 50 & 42.0 & -0.5 & 24.7 & 0.5 \\
\hline Hail & $27^{\circ} 31^{\prime} \mathrm{N}, 41^{\circ} 41^{\prime} \mathrm{E}$ & 1002 & 116 & 43.5 & -9.4 & 21.5 & 6.6 \\
\hline Taif & $21^{\circ} 16^{\prime} \mathrm{N}, 40^{\circ} 25^{\prime} \mathrm{E}$ & 1453 & 204 & 39.5 & -1.2 & 22.9 & 12.1 \\
\hline
\end{tabular}


Pallas have been recorded in the high lava fields and Indian crested porcupine Hystrix indica Kerr are also recorded. Key bird species include griffon vulture Gyps fulvus Hablizl, Hume's tawny owl Strix butleri Hume, Sinai rosefinch Carpodacus synoicus Temminck, and Arabian red-legged partridge Alectoris melanocephala Ruppell. The Palaearctic relict lizard Laudakia stellio brachydactyla Haas has been recorded from the locality.

Although systematic floristic surveys have not yet been undertaken, a series of visits to the site have begun to build up qualitative descriptions of the vegetation. Preliminary surveys have recorded 160 plant species from Jabal Qaraqir (see Appendix 1). For the purposes of this IPA assessment, the area can be roughly divided into three major plant habitats: the volcanic plateau of the Harrat ar-Raha, the sandstone slopes and the wadi valleys.

\section{HARRAT AR-RAHA \\ Geology and climate}

Along the northern and eastern edges of Jabal Qaraqir, late Cambrian and Ordovician sandstones are overlain by the Quaternary lava fields of Harrat ar-Raha and Harrat 'Uwayrid, composed of basal picrite-ankaramite lavas overlain by alkaliolivene basalt with scattered volcanic necks, plugs, ring dikes and domes. On this volcanic plateau there are small areas of shallow stony soils and saline silts in depressions, with some fertile soils in the clefts of volcanic peaks.

On the edge of the Raha escarpment, the $40 \mathrm{~mm}$ of annual rainfall recorded in Ad-Disah is probably at least doubled by orographic rainfall from the convective cooling of humid Red Sea air brought in by the prevailing wind over the high mountains. This convective cooling increases cloudiness and in winter causes light falls of snow and hail.

As no precise climatic data are available for the Harrat ar-Raha, extrapolations have been made based upon the average data for Tabuk and using the environmental lapse rate $\left(6.4^{\circ} \mathrm{C} / 1000 \mathrm{~m}\right)$ and microclimatic observations on site. Summer and winter temperatures on the Hisma plateau $(1000-1250 \mathrm{~m})$ may be $6-8^{\circ} \mathrm{C}$ cooler than average, on the Raha escarpment $(1250-1750 \mathrm{~m}) 8-11^{\circ} \mathrm{C}$ cooler, and on the mountains above $1750 \mathrm{~m}, 11-14^{\circ} \mathrm{C}$ cooler, and so similar to areas much further north.

\section{Flora}

On the lava-covered plateau of Harrat ar-Raha/Harrat 'Uwayrid, the vegetation is relatively sparse (see Fig. 3). The dominant tree is Acacia gerrardii var. najdensis (for authorities see Appendix 1) but this is very thinly scattered. Relatively common herbs and shrubs include Aerva javanica, Artemisia sieberi, Caylusea hexagyna, Centaurea pseudosinaica, Echinops hystrichoides, Ferula ovina, F. rutbaensis, Gomphocarpus sinaicus, Paracaryum intermedium, Peganum harmala, Pulicaria crispa, 


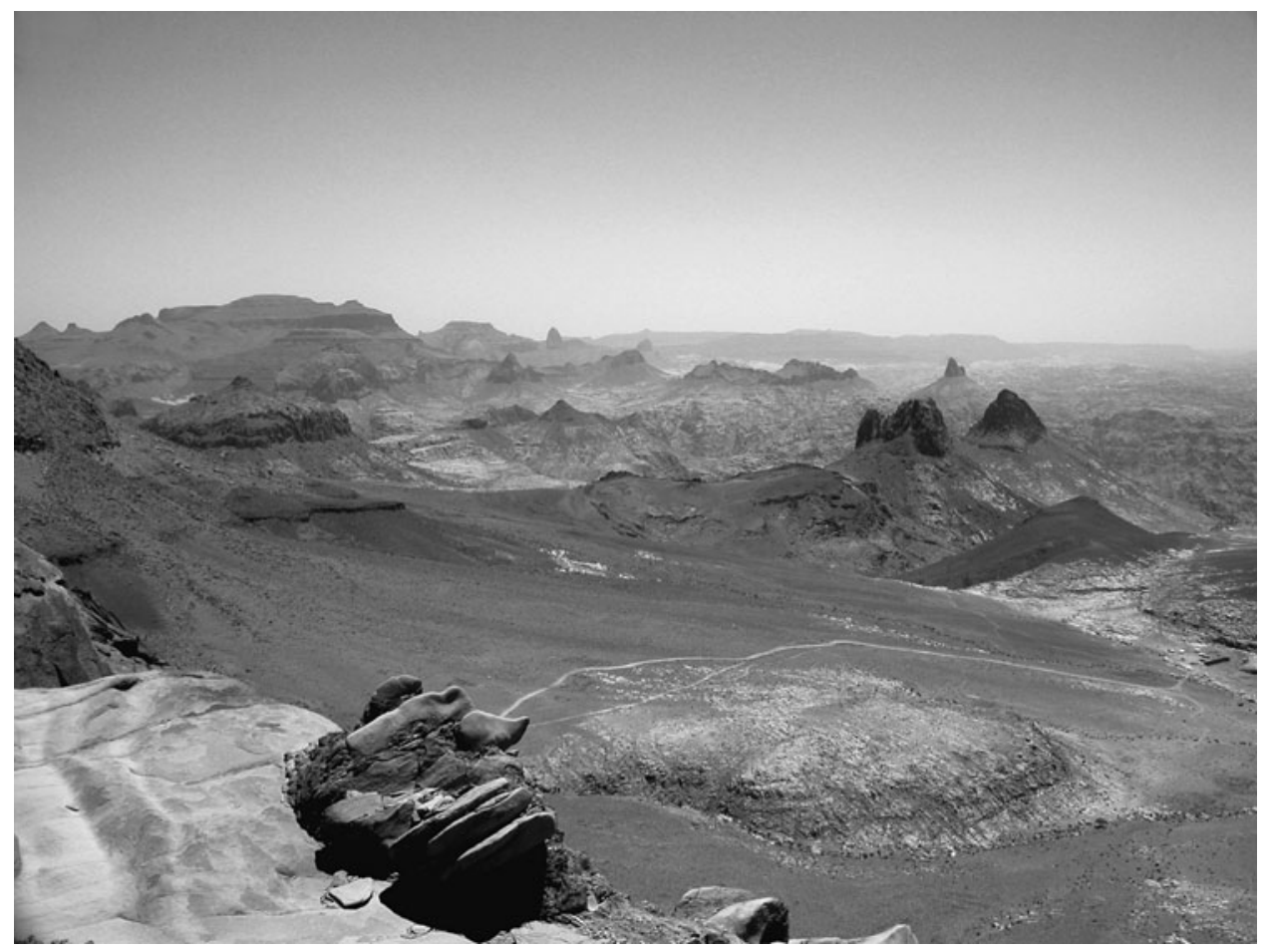

FIg. 3. The lava flows of the Harrat ar-Raha are one of the most important sites for plant biodiversity in the Jabal Qaraqir area.

Salsola tetrandra, Scandix stellata, Senecio glaucus, Sisymbrium erysimoides, Retama raetam and Zilla spinosa. Grass species include Cymbopogon schoenanthus, Bromus fasciculatus and Pennisetum setaceum. Tree-sized Sageretia thea and populations of Irano-Turanian elements such as Delphinium sheilae and Mediterranean elements such as Alcea striata grow in clefts on the sides of volcanic plugs.

The Zawiyah plateau lies west of the Harrat ar-Raha and $300-400 \mathrm{~m}$ below it. It receives little water (the Ruwafah area is known as Ard az-Zama', the Land of Thirst). The valleys between the lava-capped mesas and the level plain are covered with alluvial hill wash, gravel and sand. The vegetation is heavily grazed and, along with sparse Acacia tortilis, the resulting dominant is Haloxylon salicornicum with some Retama raetam. Schimpera arabica is widespread in spring.

The southern fringe of the Harrat ar-Raha lies over rounded white and buff Ram sandstone, which extends over half the crest area of the inaccessible pinnacles. Between the expanses of bare rock are relatively fertile flats and cracks. Plant species recorded from this habitat include Helianthemum lippii, Ochradenus baccatus, Asphodelus tenuifolius, Anisosciadium lanatum, Ballota undulata, Fagonia tristis, Launaea spinosa, Matthiola arabica, Rumex vesicarius and Trigonella stellata. Grasses 
occurring here include Stipagrostis foëxiana, S. plumosa and Cymbopogon schoenanthus. Some unpalatable species include Iphiona mucronata and Chiliadenus montanus. Occasional trees of Ficus cordata subsp. salicifolia and Pistacia cf. khinjuk also occur. In one north-facing cleft at approximately $1050 \mathrm{~m}$ a small Juniperus phoenicea has been recorded.

\section{Rare species}

This relatively cool, humid highland is a major site in the Qaraqir area for a number of Irano-Turanian and Mediterranean biogeographic relicts. The high peaks and slopes of the Harrat ar-Raha are some of the most interesting botanical localities in the north of Arabia. This is the only site in Saudi Arabia where Alcea striata and Salvia palaestina are recorded. The Harrat is also one of two sites in Saudi Arabia where the species Pterocephalus brevis (also on Jabal Aja'), Globularia arabica (also on Jabal Dubbagh), Delphinium sheilae (Jabal Dubbagh), Satureja thymbrifolia (south of Tayma), Valerianella oxyrhyncha (Jabal Aja'), Hypericum sinaicum (previously only known from Jabal Lawz) and the subspecies Astracantha echinus subsp. arabica (Jabal Dubbagh) have been recorded. This area is also one of a handful of sites for Nepeta sheilae (endemic) (Jabal Dubbagh, Jabal Lawz, Wadi Abaida, Jabal Soodah), Phlomis brachyodon (Jabal Dubbagh, Jabal Lawz), Stachys aegyptiaca (Jabal Shaar, Jabal Dubbagh, Aqabata Jizan) and for Ephedra pachyclada subsp. sinaica (previously only known from Jabal Dubbagh, north of Aha and Jabal Shaar).

\section{SANDSTONE SLOPES}

\section{Geology and climate}

The deeply incised red Quweira and Siq sandstone canyon lands underlie the Ram formation from about 600 to $1100 \mathrm{~m}$. Their steep sides make them almost inaccessible to goats, but only ridges and cracks remain vegetated. As for the rest of Jabal Qaraqir, there are no precise climatic data available for this area. The sandstone slopes are likely to receive rainfall amounts above the average for AdDisah $(40 \mathrm{~mm})$ due to orographic rainfall, but much of this is likely to flow through the porous and deeply fissured sandstones, towards the wadi valleys below. Temperatures are likely to be lower than the average for Tabuk (following the environmental lapse rate of $6.4^{\circ} \mathrm{C} / 1000 \mathrm{~m}$ ) depending on altitude.

\section{Flora}

The plants in order of dominance are: Lycium shawii (mainly on the lower slopes), Ochradenus baccatus, Gymnocarpos decandrus, Polygala schwartziana, Helianthemum lippii, Pterogaillonia calycoptera and Ephedra pachyclada subsp. sinaica. Two perennial 
grasses commonly occur: Hyparrhenia hirta and Oryzopsis holciformis subsp. abyssinica. In addition there are many trees of Acacia tortilis mainly in the wider wadis. Among the pinnacles are sparsely distributed low shrubs, including Otostegia fruticosa, Stachys aegyptiaca, Lavandula coronopifolia, Retama raetam, Haloxylon salicornicum (both common in dry sands but occasionally on the rocky slopes), Fagonia mollis, Teucrium leucocladum, Farsetia aegyptia and Capparis spinosa.

On the rocky sandstone slopes located between the Harrat ar-Raha and the intermontane plain of Wadi Ash-Shijnah occurs a very sparse, low shrubland comprised of Anvillea garcinii, Astragalus spinosus, Ochradenus baccatus, Retama raetam and Zilla spinosa. This sparse vegetation is also comprised of a number of herbaceous species including Asteriscus pygmaeus, Centaurea eryngioides, Centaurea sinaica, Echium rauwolfi, several species of Erodium (E. hirtum, E. malacoides, E. neuradifolium, E. oxyrhynchum), Gymnocarpos decandrus and Rumex nervosus.

\section{Rare species}

There are no rare species currently recorded from the sandstone slopes of Jabal Qaraqir.

\section{WADi VALLEYS \\ Geology and climate}

The geology of the site is composed mainly of late Cambrian and Ordovician sandstones. These overlie metamorphosed Precambrian volcanic and volcaniclastic basement rocks of the Arabian Shield, mixed with green schist and sedimentary rock. The floors of the canyons and lowlands along the southwest are overlain by Quaternary deposits of talus, alluvial fans, alluvium, and aeolian sands. The dominant soils are lithosols with pockets and channels of richer alluvium, and alluvial sands. Deep loamy stratified non-saline to slightly saline torrifluvents and torriorthents occur in canyon beds and floodplains. In sandy wadi beds and plains there are deep non-saline to very slightly saline soils with rapid permeability and moderately low water retention.

The high lava escarpment attracts orographic rain and snow, which runs through the porous and deeply fissured sandstones, surfacing on the rock floors of the deeper canyons, where the wadi bed sediments form a sponge above the impermeable basement rock. Perennial springs are found in Wadi Qaraqir, Wadi Amdan and Wadi as-Sukhnah, with near-perennial springs in Wadi Ghamrah and Wadi Anqad/ Yanqad. These seeps and springs give rise to a unique wetland habitat in this otherwise very arid area with an annual rainfall of less than $50 \mathrm{~mm}$ a year. Temperatures in the canyons may be assumed to be a little cooler than the (Tabuk) average in winter, but may be $4-5^{\circ} \mathrm{C}$ hotter than average in summer. 


\section{Flora}

Wet wadi floors, streambanks, springs and seeps occur at the foot of the Quweira sandstone $(600-700 \mathrm{~m})$ and are vegetated with a luxuriance which is remarkable for an arid area and unique in the northwest of Saudi Arabia. These wadi floors (such as those in Wadi Qaraqir and Wadi Ghamrah) have dense thickets of Nerium oleander. Open water areas support submerged aquatic plants such as Myriophyllum spicatum. There are also long banks of 3-4 m high Phragmites australis, large tussocks of Saccharum ravennae, and, along streambeds, Typha domingensis, doum palms Hyphaene thebaica, and date palms Phoenix dactylifera (see Fig. 4). Acacia tortilis and shrubby Tamarix nilotica are also common. The erect herbs Verbascum sheilae and Verbascum sinaiticum are also found in the sandy soils of the wadi beds. Where there is moisture on cliff-sides Ficus cordata subsp. salicifolia and F. palmata subsp. virgata typically occur. Seeps are usually covered with the fern Adiantum capillusveneris. The orchid Epipactis veratrifolia has been recorded from a calcareous seep in the Jabal Qaraqir area.

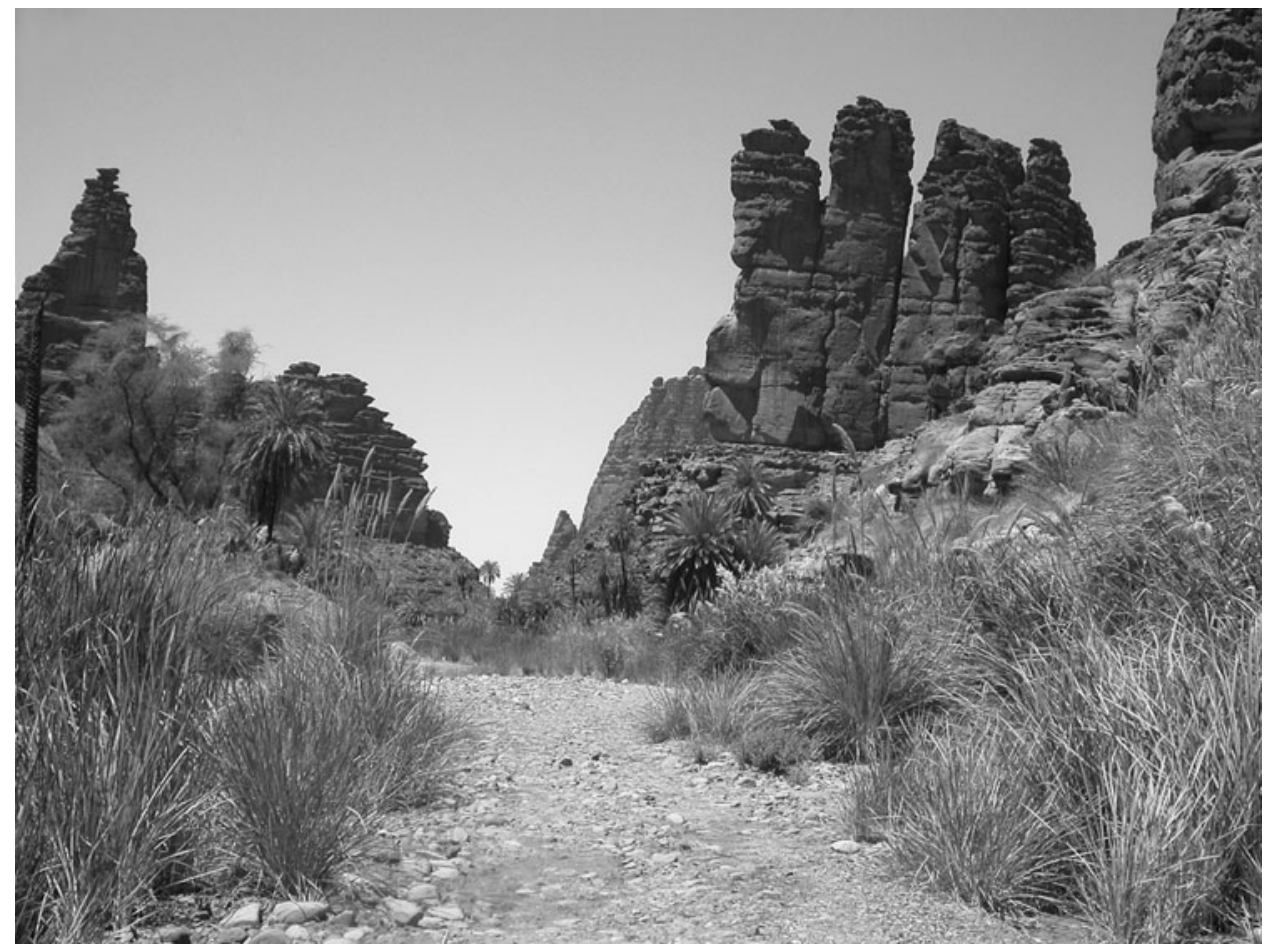

FIg. 4. Wadi Ghamrah contains some of the best wet wadi vegetation in Saudi Arabia. Nerium oleander, Phragmites australis, Saccharum ravennae, Typha domingensis, Hyphaene thebaica and Phoenix dactylifera are all abundant along this watercourse. 
The dry wadi floors, wadi mouths, and sands are flat and heavily overgrazed. In Wadi Ash-Shijnah, the resulting dominant tree species is Acacia tortilis with Ficus cordata subsp. salicifolia occurring at the foot of cliffs. The most abundant shrubs are Haloxylon salicornicum, Retama raetam and Lycium shawii, along with Fagonia ovalifolia and Gomphocarpus sinaicus. The herbs Asphodelus tenuifolius and Otostegia fruticosa are relatively common. Pennisetum divisum and Senna italica are found on the plains. The flower spikes of Cistanche phelypaea (which is parasitic on the Haloxylon) are conspicuous in early spring. In the mouths of Wadi Tirban and Wadi Qaraqir are the degraded remnants of extensive groves of large Tamarix aphylla which have been lopped to feed camels. Local people claim the dieback is due to lowered groundwater, but the surviving foliage is healthy.

\section{Rare species}

A number of endemic and geographically restricted plant species occur in the wet wadi valleys of Jabal Qaraqir. The endemic crucifer Douepea arabica (Hedge \& Kit Tan) O.Appel \& Al-Shehbaz, which was previously known only from Wadi Qaraqir (Collenette $874(\mathrm{~K})$ - Dolichorhynchus arabicus), was recorded in the adjacent Wadi Ghamrah, during field studies in May 2008. Nine mature individuals were recorded in sandy soils, with over 30 seedlings also present. This species is associated with seepages and is found alongside large stands of Nerium and Pennisetum; none were recorded on the drier slopes. This endemic has been assessed for the IUCN Red List as Critically Endangered (Hall et al., in press).

Three other rare species recorded from the wet wadi beds in Wadi Qaraqir and Wadi Ghamrah are the Saudi Arabian endemics Reseda pentagyna, Verbascum deserticola and $V$. sheilae. Verbascum deserticola was noted for the first time in Wadi Ghamrah during field studies in May 2008.

The wet wadi valleys of Jabal Qaraqir (e.g. Wadi Qaraqir, Wadi Ghamrah) are also the only places in Saudi Arabia where the oleander Nerium oleander grows wild and are one of a handful of sites for Verbascum sinaiticum (Jabal Lawz), Teucrium leucocladum (Jabal Dubbagh, Jabal Lawz) and Echinops glaberrimus (Jabal Dubbagh, Jabal Lawz). Wadi Shignah, at the head of Wadi Qaraqir, is the only known Arabian site for Chaetosciadium trichospermum. These valleys are also one of two known localities in Saudi Arabia for the orchid Epipactis veratrifolia (also in Lejib gorge) (Collenette, 1999).

\section{IPA Assessment}

Jabal Qaraqir is an important site for conservation in Arabia. Scott (1995) considers the area of Wadi Qaraqir to be a site of international significance as a RAMSAR wetland. Jabal Qaraqir is also an important site for wild plant conservation, and using the adapted Arabian criteria (Al-Abbasi et al., 2010) Jabal Qaraqir qualifies as an IPA (see Table 2). 
TABLE 2. Jabal Qaraqir qualifies as an IPA under criteria A (1-5) and B (1 \& 2)

\section{Criterion A}

A1 - Globally threatened taxa

A2/A3 - Regionally/nationally threatened taxa

A4 - National endemic, near endemic, regional endemic and/or regional range-restricted taxa

A5 - Species of special interest

\section{Criterion B}

B1 - Species-rich example of a defined habitat type in Arabia

B2 - Biogeographic and bioclimatic refuge

\section{Criterion C}

C1 - Outstanding example of a globally or regionally threatened habitat type
Wet wadis of Qaraqir and Ghamrah are the only known localities for Douepea arabica and Reseda pentagyna and one of very few known locations for Verbascum deserticola and Nepeta sheilae (Chaudhary, 2001).

In addition to those above, Jabal Qaraqir has 18 regionally/nationally rare taxa: Nerium oleander, Verbascum sinaiticum, Teucrium leucocladum, Echinops glaberrimus, Chaetosciadium trichospermum, Alcea striata, Pterocephalus brevis, Globularia arabica, Delphinium sheilae, Hypericum sinaicum, Satureja thymbrifolia, Phlomis brachyodon, Astracantha echinus subsp. arabica, Salvia palaestina, Epipactis veratrifolia, Ephedra pachyclada subsp. sinaica, Stachys aegyptiaca and Valerianella oxyrhyncha.

Douepea arabica, Verbascum deserticola, Nepeta sheilae and Reseda pentagyna are all Saudi Arabian endemics.

Douepea arabica is an important wild relative of cultivated Cruciferae.

The areas of Nerium shrubland with Phragmites and Typha are some of the best preserved and most species-rich examples of this wet wadi habitat in Arabia.

(a) Elements from several biogeographical zones, including Mediterranean, IranoTuranian and Somalia-Masai. Notable species are Alcea striata (Irano-Turanian) which is only known from Jabal Qaraqir and Delphinium sheilae which is only known from two sites in Arabia.

(b) With lower temperatures and higher available moisture, the high peaks and slopes of the Harrat ar-Raha are an important refuge for geographically and bioclimatically restricted plants to 'retreat to' in the face of climatic change.

There are currently no regionally or globally threatened habitats on Jabal Qaraqir. 


\section{SOCIO-ECONOMIC ISSUES}

The dominant occupation of the human population around the Wadi Qaraqir area is grazing of domestic livestock. In the canyons a few small farms grow a variety of crops, mainly vegetables and fruits. As the canyons are subject to flash floods, there is a real threat of damage to both people and property. On the less rugged sandstone slopes there is minor grazing of camels, sheep and goats. Farmland is individually owned, its development dependent on sinking wells. Use of these wells is said to have lowered the water table downstream. No existing or former himas are known to exist in the proposed protected area (Llewellyn, 2003), nor any traditional agricultural terraces, rainwater harvesting systems or other initiatives to conserve plant or animal populations.

This scenic site is comparable with the world-famous canyons of the SW United States and offers a significant opportunity to develop nature-based tourism in a manner that would benefit local communities and provide an incentive for environmental protection. The Jabal Qaraqir area contains sites of archaeological interest, notably the Roman/Nabatean building Qasr Ruwafah, the Nabatean tomb door at Ad-Disah, and various inscriptions and petroglyphs.

Jabal Qaraqir is within relatively close proximity to the city of Tabuk $(80 \mathrm{~km})$ and the town of Duba $(8 \mathrm{~km})$. As of May 2008, the main wadi valleys of Wadi Qaraqir and Wadi Ash-Shijnah are directly connected by road to these well-populated areas. As with other road-building exercises in Arabia, the opening up of this beautiful area will result in a great increase in the number of people visiting the area for recreation. Visits to the site in May 2008 noted significant increases in visitor numbers on previous years.

\section{THREATS TO CONSERVATION}

There are a number of existing and potential threats to the conservation of Jabal Qaraqir, both as an Important Plant Area and as a site of natural and cultural heritage. The wetland vegetation in the lower reaches of the canyons (e.g. Wadi Qaraqir) is gradually deteriorating as a result of agricultural activities. Modifications are being made to the stream course to create fields and the groundwater flow is being broken by the intrusion of wells for irrigation. Pumping water for small farms upstream has already lowered the water table in the nearby town of Ad-Disah, where salination of fields has already been recorded. Reduction of available water in Wadi Qaraqir would seriously threaten the persistence of the wetland biodiversity. Overgrazing is the other major threat to plant conservation. This is evident on the Harrat ar-Raha, but is especially evident in the wadis where even toxic plants have been grazed. Overuse of plant resources in the area is also a major problem. For example, large groves of Tamarix trees in the wadis have been lopped for camel fodder to the point of destruction. Local farmers also cut and burn the Nerium shrubs in order to replace them with grass for grazing. Deterioration from agriculture is likely to increase with increasing numbers of small farms in the area. 
From previous case studies in Arabia, the construction of a major new road through Jabal Qaraqir (Wadi Qaraqir and Wadi Ash-Shijnah) will also pose serious challenges for biodiversity conservation (Hall et al., 2008). The construction of the road in Wadi Qaraqir has already resulted in significant clearing of wadi vegetation and scarring of the natural rock formations through quarry blasting (see Fig. 5). As well as the physical damage to rock formations and vegetation through road construction, particular problems are envisaged with increasing access to an otherwise isolated area. Significant threats may emerge from increased settlement and agricultural expansion in the area. Increased road access to Jabal Qaraqir also has the potential to increase hunting of the area's prominent mammals, offroad driving and littering. Indeed, field visits to the area in May 2008 recorded a great increase in littering from visitors accessing the site from the new road. Also accompanying these visits was an increase in graffiti scrawled on the rock faces and, significantly for cultural heritage conservation, over large sections of petroglyphs.

For plant biodiversity, increased access to the site and increased resource use threatens to degrade the wetland vegetation that qualifies Jabal Qaraqir as an IPA under criterion $\mathrm{B}$. These factors also present a significant conservation threat to the rare and endemic plant species which make Jabal Qaraqir an IPA under criterion A. Of particular concern is the regeneration of the Critically Endangered endemic species Douepea arabica which is restricted to the alluvial wadi valleys that are the

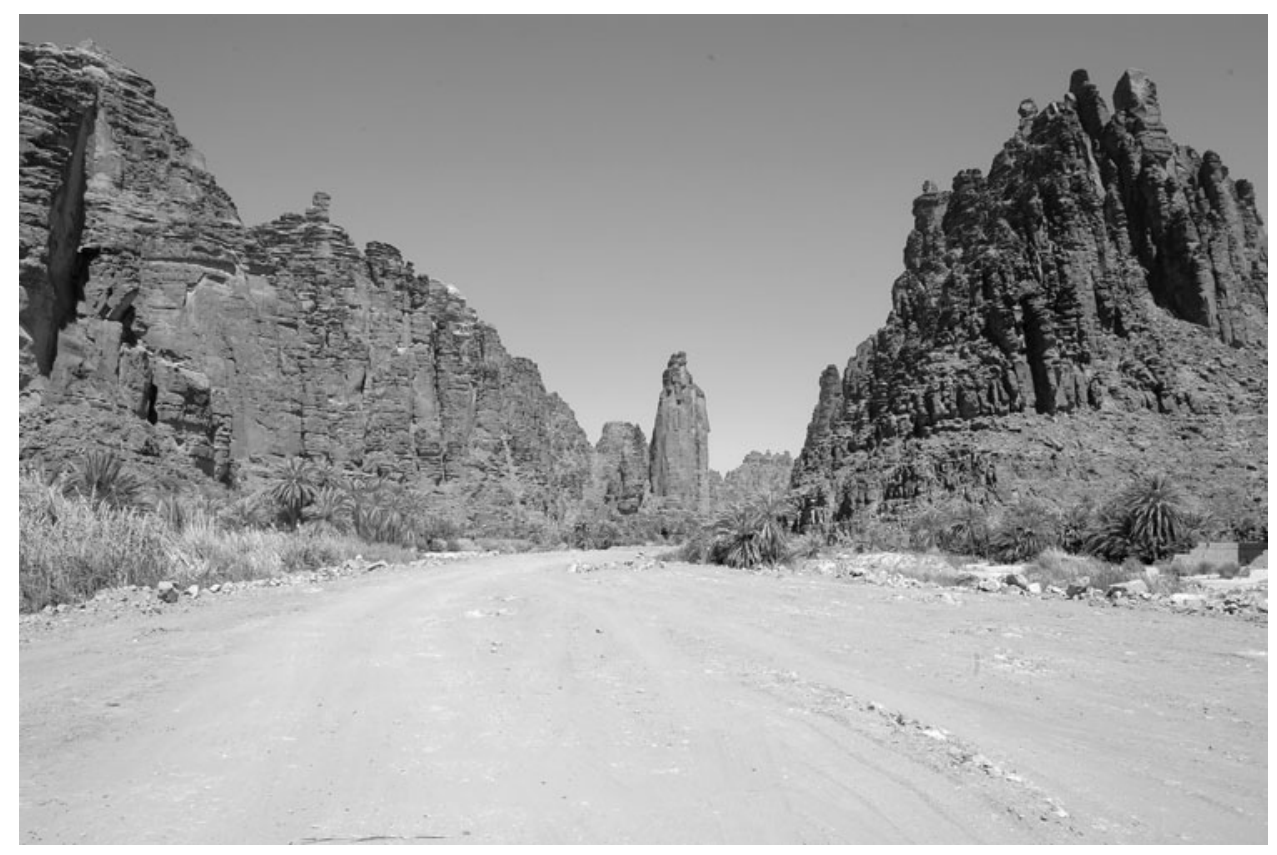

FIG. 5. The construction of a new road has caused considerable damage to the wet wadi vegetation of Wadi Qaraqir, posing a significant threat to the persistence of the endemic species Douepea arabica. 
major focus of road building and agricultural expansion. In order to safeguard the existence of these species, significant conservation initiatives are required for Jabal Qaraqir.

Jabal Qaraqir is currently proposed as a part of a protected area network under Saudi legislation. Such conservation planning is well supported by the IPA assessment programme, but here we offer a number of important points regarding the implementation of conservation action in Jabal Qaraqir. As well as legislation, effective conservation requires full engagement with local stakeholders, in this case the local people who populate the area. Conservation action needs to offer opportunities for local people to reduce their potential impact on the biodiversity of Jabal Qaraqir, either through alternative employment or through the provision of alternative (preferably improved) land for cultivation and habitation.

\section{FURTHER RESEARCH}

Although enough data are available to list Jabal Qaraqir as an Important Plant Area, the biodiversity of the area is still poorly known. Extensive botanical research is needed in the following areas:

1 Comprehensive surveys to build up a basic inventory of the plants in the area.

2 Floristic and vegetation studies to determine and map the major vegetation types.

3 Recording and mapping the distribution of rare and endemic plant species.

In view of the threats to the rare habitats and species in Jabal Qaraqir, the establishment of effective, targeted monitoring programmes should be a matter of priority. Similarly, zoological studies are needed to complete the preliminary surveys of mammals, birds and reptiles. The ruggedness of the site must conceal considerable wildlife and these inventories are far from complete. Perhaps the most pressing zoological research is to determine the population size and health of the ibex population. Again, in view of the changes occurring in Jabal Qaraqir, the establishment of a monitoring programme for prominent fauna (such as ibex) must be a priority for conservation planning. Lastly, any serious conservation planning within the Jabal Qaraqir area should implement proper socio-economic research programmes to examine ways in which to engage local stakeholders (Margules \& Pressey, 2000).

\section{REFERENCES}

Al-Abbasi, T. M., Al-Farhan, A., Al-Khulaidi, A. W., Hall, M., Llewellyn, O. A., Miller, A. G. \& Patzelt, A. (2010). Important Plant Areas in the Arabian Peninsula. Edinburgh J. Bot. 67: 25-35.

Anderson, S. (2002). Identifying Important Plant Areas. Plantlife International.

Angiosperm Phylogeny Group (2003). An update of the Angiosperm Phylogeny Group classification for the orders and families of flowering plants: APG II. Bot. J. Linn. Soc. 141: 399-436. 
Chaudhary, S. A. (2001). Flora of the Kingdom of Saudi Arabia (Illustrated), Vol. 2(2). Riyadh: Ministry of Agriculture and Water.

Collenette, S. (1999). Wildflowers of Saudi Arabia. Riyadh: NCWCD.

Ghazanfar, S. A. \& Fisher, M. (1998). Vegetation of the Arabian Peninsula. London: Kluwer.

Hall, M., Al-Khulaidi, A. W., Miller, A. G., Scholte, P. \& Al-Qadasi, A. H. (2008). Arabia's last forests under threat: Plant biodiversity and conservation in the valley forest of Jabal Bura (Yemen). Edinburgh J. Bot. 65: 113-135.

Hall, M., Miller, A. G., Llewellyn, O., Abbasi, T. M., Al-Harbi, R. J., AlWetaid, A. H. \& Al-Shammari, K. F (In press). A conservation assessment of Douepea arabica (Brassicaceae) - a Critically Endangered plant species from Saudi Arabia. Oryx.

IUCN (2007). Identification and Gap Analysis of Key Biodiversity Areas: Targets for Comprehensive Protected Areas Systems. Gland, Switzerland: IUCN.

Knight, A. T., Smith, R. J., Cowling, R. M., Desmet, P. G., Faith, D. P., FERRIER, S. et al. (2007). Improving the Key Biodiversity Areas approach for effective conservation planning. BioScience 57: 256-261.

Llewellyn, O. A. (2003). The basis for a discipline of Islamic environmental law. In: Foltz, R. C. et al. (eds) Islam and Ecology, pp. 185-247. Cambridge, MA: Harvard University Press.

Margules, C. R. \& Pressey, R. L. (2000). Systematic conservation planning. Nature 405: 243-253.

Miller, A. G. \& Cope, T. A. (1996). Flora of the Arabian Peninsula and Socotra, Vol. 1. Edinburgh: Edinburgh University Press.

Plantlife International (2004). Identifying and Protecting the World's Most Important Plant Areas. Salisbury: The Important Plant Area Secretariat, Plantlife International.

Scott, D. (1995). A Directory of Wetlands in the Middle East. Gland, Switzerland: IUCN. Secretariat of the Convention on Biodiversity (2002). Global Strategy for Plant Conservation. Secretariat of the Convention on Biodiversity and Botanic Gardens Conservation International.

Received 3 March 2009; accepted for publication 11 November 2009

\section{APPENDIX 1}

Checklist of plant taxa from Jabal Qaraqir. Family delimitation follows APG II (Angiosperm Phylogeny Group, 2003)

This checklist is compiled from survey data, literature sources and herbarium specimens. The principal source for each record is noted in superscript next to each name (1 - IPA Survey Data 2008; 2 - National Commission for Wildlife Conservation and Development (NCWCD) Field Surveys; 3 - Collenette, 1999). Taxa known only from herbarium specimens also have the herbarium specimen listed.

\section{Acanthaceae}

Blepharis ciliaris (L.) B.L.Burtt ${ }^{1}$

\section{Adiantaceae}

Adiantum capillus-veneris $\mathrm{L}^{1}$ 
Aizoaceae

Aizoon canariense L. ${ }^{1}$

Alliaceae

Allium dictyoprasum C.A.Mey. ex Kunth ${ }^{3}$

Amaranthaceae

Aerva javanica (Burm.f.) Juss. ex Schult. ${ }^{1}$

Anacardiaceae

Pistacia cf. khinjuk Stocks ${ }^{1}$

Pistacia falcata Becc. ex Martelli ${ }^{1}$

Apocynaceae

Nerium oleander L. ${ }^{1}$

Asclepiadaceae

Gomphocarpus sinaicus Boiss. ${ }^{1}$

\section{Asparagaceae}

Asparagus aphyllus L. ${ }^{1}$

\section{Asphodelaceae}

Asphodelus tenuifolius Cav. ${ }^{1}$

\section{Boraginaceae}

Echium rauwolfii Delile ${ }^{1}$

Heliotropium ramosissimum (Lehm.) Sieber ex A.DC. ${ }^{1}$

Lappula spinocarpa (Forssk.) Asch. ex Kuntze ${ }^{1}$

Paracaryum intermedium (Fresen.) Hiliger \& Podlech ${ }^{1}$

\section{Capparaceae}

Capparis spinosa $\mathrm{L} .{ }^{1}$

Maerua crassifolia Forssk. ${ }^{2}$

\section{Caryophyllaceae}

Dianthus strictus Banks \& Sol. ${ }^{1}$

Gymnocarpos decandrus Forssk. ${ }^{1}$

Polycarpaea robbairea (Kuntze) Greuter \& Burdet $^{1}$

Silene sp. aff. grisea Boiss. ${ }^{3}$

\section{Chenopodiaceae}

Haloxylon salicornicum (Moq.) Boiss. ${ }^{1}$

Salsola tetrandra Forssk. ${ }^{1}$

\section{Cistaceae}

Helianthemum lippii (L.) Dum.Cours. ${ }^{2}$

\section{Compositae}

Anvillea garcinii (Burm.f.) DC. ${ }^{1}$

Artemisia sieberi Besser (syn. Artemisia herba-alba Asso) ${ }^{1}$

Asteriscus pygmaeus (DC.) Coss. \& Durieu ${ }^{1}$

Atractylis carduus (Forssk.) C.Chr. ${ }^{1}$

Centaurea eryngioides Lam. ${ }^{1}$

Centaurea pseudosinaica Czerep. ${ }^{1}$

Centaurea sinaica DC. ${ }^{1}$

Chiliadenus montanus (Vahl) Brullo ${ }^{3}$ 
Echinops glaberrimus DC. ${ }^{1}$

Echinops hystrichoides Kit Tan ${ }^{1}$

Iphiona mucronata (Forssk.) Asch. \& Schweinf. [Grainger 12630 (RIY)]

Launaea spinosa (Forssk.) Sch.Bip. ${ }^{1}$

Leysera leyseroides (Desf.) Maire ${ }^{1}$

Pulicaria crispa (Forssk.) Oliv. ${ }^{1}$

Senecio glaucus $\mathrm{L}^{1}$

Tanacetum sinaicum (Fresen.) Delile ex K.Bremer \& Humphries ${ }^{2}$

Zoegea purpurea Fresen. ${ }^{1}$

Convolvulaceae

Convolvulus hystrix Vahl $^{1}$

Crassulaceae

Umbilicus horizontalis (Guss.) DC. ${ }^{1}$

Cruciferae

Aethionema carneum (Banks \& Sol.) B.Fedtsch. [Collenette 9296 (RIY)]

Biscutella didyma $\mathrm{L} .{ }^{1}$

Diplotaxis harra (Forssk.) Boiss. ${ }^{1}$

Douepea arabica (Hedge \& Kit Tan) O.Appel \& Al-Shehbaz ${ }^{1}$

Eremobium aegyptiacum (Spreng.) Asch. \& Schweinf. ex Boiss. ${ }^{1}$

Farsetia aegyptia Turra $^{1}$

Isatis lusitanica $\mathrm{L} .{ }^{1}$

Matthiola arabica Boiss. [Grainger 12631 (RIY)]

Matthiola longipetala (Vent.) DC. ${ }^{1}$

Morettia canescens Boiss. ${ }^{1}$

Sisymbrium erysimoides Desf. ${ }^{1}$

Zilla spinosa (L.) Prantl ${ }^{1}$

Cucurbitaceae

Citrullus colocynthis (L.) Schrad. ${ }^{1}$

Cucumis prophetarum L. var. dissectus (Naudin) C.Jeffrey ${ }^{1}$

Cupressaceae

Juniperus phoenicea $\mathrm{L}^{2}$

Dipsacaceae

Pterocephalus brevis Coult. ${ }^{2}$

Ephedraceae

Ephedra aphylla Forssk. ${ }^{1}$

Ephedra pachyclada Boiss. subsp. sinaica (H.Riedl) Freitag \& Maier-Stolte ${ }^{1}$

Euphorbiaceae

Chrozophora oblongifolia (Delile) A.Juss. ex Spreng. ${ }^{1}$

Geraniaceae

Erodium hirtum (L.) Willd. ${ }^{1}$

Erodium malacoides (L.) L’Hér. ${ }^{1}$

Erodium neuradifolium Delile ex Godr. ${ }^{1}$

Erodium oxyrhynchum M.Bieb. ${ }^{1}$

Globulariaceae

Globularia arabica Jaub. \& Spach ${ }^{2}$ 


\section{Gramineae}

Bromus fasciculatus C.Presl ${ }^{1}$

Cenchrus pennisetiformis Hochst. \& Steud. [Collenette 8575 (K)]

Cymbopogon schoenanthus (L.) Spreng. ${ }^{1}$

Hyparrhenia hirta (L.) Stapf ${ }^{2}$

Imperata cylindrica (L.) Raeusch. ${ }^{1}$

Panicum turgidum Forssk. ${ }^{1}$

Pennisetum divisum (J.F.Gmel.) Henrard ${ }^{1}$

Pennisetum setaceum (Forssk.) Chiov. ${ }^{1}$

Phragmites australis (Cav.) Trin. ex Steud. ${ }^{1}$

Piptatherum holciforme (M.Bieb.) Roem. \& Schult. [syn. Oryzopsis holciformis

(M.Bieb.) Hack. subsp. abyssinica (Freitag) D.Heller] ${ }^{2}$

Polypogon viridis (Gouan) Breistr. [Collenette $9366(\mathrm{~K})$ ]

Saccharum ravennae (L.) Murr. ${ }^{1}$

Stipa cf. arabica ${ }^{1}$ [The specimen collected from J. Qaraqir, Miller 41450 (E), has shorter awns than usual for this species and identification requires confirmation.

This would represent a new record for this species in Arabia.]

Stipagrostis ciliata (Desf.) De Winter ${ }^{1}$

Stipagrostis foëxiana (Maire \& Wilczek) De Winter ${ }^{2}$

Stipagrostis obtusa (Delile) Nees ${ }^{1}$

Stipagrostis plumosa (L.) Munro ex T.Anderson ${ }^{2}$

Tricholaena teneriffae (L.f.) Link $^{1}$

Haloragaceae

Myriophyllum spicatum $\mathrm{L}^{1}$

Hypericaceae

Hypericum sinaicum Hochst. ex Boiss. ${ }^{1}$

Iridaceae

Gynandriris sisyrinchium (L.) Parl. ${ }^{2}$

\section{Labiatae}

Ballota undulata (Sieber ex Fresen.) Benth. ${ }^{1}$

Lavandula coronopifolia Poir. ${ }^{1}$

Lavandula pubescens Decne. ${ }^{1}$

Mentha longifolia (L.) L. ${ }^{1}$

Micromeria imbricata (Forssk.) C.Chr. ${ }^{1}$

Nepeta sheilae Hedge \& R.A.King ${ }^{1}$

Otostegia fruticosa (Forssk.) Schweinf. ex Penzig ${ }^{1}$

Phlomis brachyodon (Boiss.) Zohary ex Rech.f. ${ }^{1}$

Salvia palaestina Benth. ${ }^{1}$

Satureja thymbrifolia Hedge \& Feinbrun ${ }^{3}$

Stachys aegyptiaca Pers. ${ }^{1}$

Teucrium leucocladum Boiss. ${ }^{3}$

Teucrium popovii R.A.King [Described as a distinct species from T. leucocladum on account of its relatively long, curved calyces and c.10 mm long corollas (Chaudhary, 2001). In this critical group, more extensive collections are needed before determining the status of this putatively endemic taxon. Existing collections from Wadi Qaraqir/Ghamrah are Collenette $9151(\mathrm{E}), 9152(\mathrm{E}), 9074(\mathrm{E})$.]

\section{Leguminosae}

Acacia gerrardii Benth. var. najdensis Chaudhary ${ }^{1}$ 
Acacia tortilis (Forssk.) Hayne subsp. raddiana (Savi) Brenan ${ }^{1}$

Astracantha echinus (DC.) Podlech subsp. arabica Hedge \& Podlech ${ }^{3}$

Astragalus spinosus (Forssk.) Muschl. ${ }^{1}$

Crotalaria persica (Burm.f.) Merr. ${ }^{1}$

Lotononis platycarpa (Viv.) Pic.Serm. ${ }^{1}$

Retama raetam (Forssk.) Webb \& Berthel. ${ }^{1}$

Senna italica Mill. ${ }^{1}$

Trigonella stellata Forssk. $^{1}$

\section{Loranthaceae}

Plicosepalus acaciae (Zucc.) Wiens \& Polhill ${ }^{1}$

\section{Malvaceae}

Alcea striata (DC.) Alef. ${ }^{3}$

\section{Moraceae}

Ficus cordata Thunb. subsp. salicifolia (Vahl) C.C.Berg ${ }^{1}$

Ficus palmata Forssk. subsp. virgata (Roxb.) Browicz ${ }^{1}$

\section{Ophioglossaceae}

Ophioglossum polyphyllum A.Braun [Collenette $1012(\mathrm{~K})$ ]

\section{Orchidaceae}

Epipactis veratrifolia Boiss. \& Hohen. ${ }^{2}$

\section{Orobanchaceae}

Cistanche phelypaea (L.) Cout. ${ }^{2}$

\section{Palmae}

Hyphaene thebaica (L.) Mart. ${ }^{1}$

Phoenix dactylifera $\mathrm{L} .{ }^{1}$

\section{Polygalaceae}

Polygala schwartziana Paiva ${ }^{1}$

\section{Polygonaceae}

Rumex nervosus $\mathrm{Vahl}^{1}$

Rumex pictus Forssk. ${ }^{3}$

Rumex vesicarius L. $^{1}$

\section{Ranunculaceae}

Delphinium sheilae Kit Tan ${ }^{1}$

\section{Resedaceae}

Caylusea hexagyna (Forssk.) M.L.Green ${ }^{1}$

Ochradenus baccatus Delile ${ }^{1}$

Reseda aucheri Boiss. var. bracteata (Boiss.) Abdallah \& De Wit ${ }^{3}$ [Miller \& Cope (1996) record this species only from the east of the Arabian Peninsula. Collenette's (1999) record may be a misidentification.]

Reseda pentagyna Abdallah \& A.G.Mill. ${ }^{1}$

\section{Rhamnaceae}

Sageretia thea (Osbeck) M.C.Johnst. ${ }^{1}$

\section{Rubiaceae}

Crucianella ciliata Lam. $^{1}$

Crucianella membranacea Boiss. $^{1}$ 
Pterogaillonia calycoptera (Decne.) Lincz. ${ }^{2}$

\section{Rutaceae}

Haplophyllum tuberculatum (Forssk.) A.Juss. ${ }^{1}$

\section{Scrophulariaceae}

Anarrhinum forskallii (J.F.Gmel.) Cufod. ${ }^{1}$

Kickxia acerbiana (Boiss.) Täckh. \& Boulos ${ }^{1}$

Lindenbergia indica (L.) Kuntze ${ }^{1}$

Verbascum deserticola (Murb.) Hub.-Mor. ${ }^{1}$

Verbascum sheilae Kit Tan [Collenette 9153 (E)]

Verbascum sinaiticum Benth. ${ }^{1}$

Verbascum sp. ${ }^{1}$

\section{Solanaceae}

Hyoscyamus pusillus L. $^{1}$

Hyoscyamus sp. aff. aureus L. ${ }^{1}$

Lycium shawii Roem. \& Schult. ${ }^{1}$

\section{Tamaricaceae}

Tamarix aphylla (L.) H.Karst. ${ }^{2}$

Tamarix nilotica (Ehrenb.) Bunge ${ }^{1}$

Typhaceae

Typha domingensis Pers. ${ }^{1}$

\section{Umbelliferae}

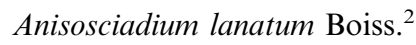

Chaetosciadium trichospermum (L.) Boiss. ${ }^{2}$

Ferula ovina Boiss. ${ }^{1}$

Ferula rutbaensis C.C.Towns. ${ }^{1}$

Ferula sinaica Boiss. $^{2}$

Pycnocycla tomentosa Decne [Collenette 9055 (E)]

Scandix stellata Banks \& Sol. ${ }^{2}$

\section{Urticaceae}

Forsskaolea tenacissima L. $^{1}$

Parietaria alsinifolia Delile ${ }^{1}$

\section{Valerianaceae}

Valerianella oxyrhyncha Fisch. \& Mey. [Collenette 6576 (12158-RIY)]

\section{Zygophyllaceae}

Fagonia indica Burm.f. [Grainger 12635 (RIY)]

Fagonia mollis Delile (syn. Fagonia tristis Sickenb.) ${ }^{2}$

Fagonia ovalifolia Hadidi $^{1}$

Peganum harmala L. ${ }^{2}$ 